Litteratur

1. Haug C. Å selge sykdom. Tidsskr Nor Legeforen 2014; 134: 1015.

2. Legemiddelindustrien. Tall og fakta 2014 - Legemidler og helsetjeneste. www.lmi.no/media/3218978/tall_og_fakta_2014.pdf (8. 6.14).

\section{Re: Å selge sykdom}

I denne lederen omtaler Haug blant annet studier om statiner (1). Når det gjelder statinbehandling av pasienter med kort forventet levetid (under ett år), viser en fersk undersøkelse at de som avslutter statinbehandlingen hadde like lang, eller lengre levetid og bedre livskvalitet enn de som fortsatte med behandlingen (2).

For pasienter som har hyppige sykehusinnleggelser er det forvirrende når sykehuset ofte gjenopptar statinbehandling som fastlegen har avsluttet - som regel uten å spørre fastlegen eller tilsynslegen om hvorfor dette har skjedd. Det foregår alt for mye forskriving styrt av retningslinjer som ikke tar hensyn til pasientens totalsituasjon.

\section{Oddmund Suhrke}

oddmund.suhrke@arendal.kommune.no

Oddmund Suhrke (f. 1953) er kommuneoverlege i Arendal kommune. Ingen oppgitte interessekonflikter.

Litteratur

1. Haug C. Å selge sykdom. Tidsskr Nor Legeforen 2014: 134: 1015.

2. Duke University Medical Center. Stopping Statins May Benefit Terminally III

Patients. http://corporate.dukemedicine.org/news_and_publications/

news_office/news/stopping-statins-may-benefit-terminally-ill-patients (5.6.14).

\section{Re: Før og nå}

Takk Steinar Solberg - for dine modige og sanne ord om hvilken skandale sammenslåingen av Oslo-sykehusene har blitt (1). Nå må vi jammen se til å våkne opp!

Denne skandalen er så gigantisk at politikerne i sin avmakt ser ut til å ha fredet hverandre. Og media fatter ikke dimensjonene, eller de sliter med å finne en forståelig vinkel for dette enorme feilgrepet som våre store partier har ansvaret for. Mot bedre vitende, mot utallige advarsler både fra politisk og faglig hold. Da prestisjen trådte inn, lot de vett og fornuft fare. Men skal vi fortsette å godta skattepengebruk på den voksende gigantskandalen?

Dersom vi skal få stoppet prestisjeforblindede politikere og ny-mektige byråkrater fra å trumfe prosessen videre, må dere, helseansatte, og vi, folket og pasienter, ta grep. Vi må organisere oss (Helsetjenesteaksjonen er et skritt på rett vei) og få oppslutning. Virkelig bred oppslutning.

Hvis folk flest forsto hva som står på spill, ville mange engasjert seg. Men så lenge media ikke evner å se gjennom dyrkjøpt PRjippo fra politikere og ledelsen ved Oslo universitetssykehus, så sliter vi med å redde dagens og fremtidens helsevesen. Det må likevel ikke hindre oss i å forsøke!

Dette handler ikke om maktkamp. Dette handler om helsefolks arbeidsliv og om pasienters liv og død. Hvorfor gjør ikke det noe som helst inntrykk på beslutningstakerne?

Lise Askvik

lise.askvik@p4.no

Lise Askvik (f. 1969) er journalist og programleder i Radio P4.

Oppgitte interessekonflikter: Tidligere kreftpasient.

Litteratur

1. Solberg S. Før og nå. Tidsskr Nor Legeforen 2014; 134: 1070

\section{Re: En mann i 80-årene med muskelstivhet og hudblødninger}

I denne kasuistikken beskrives en mann som danner autoantistoffer mot koagulasjonsfaktorer (1). Tillat meg å minne om et av versene i R. Nesbakkens medisinervise «Kanthatus internus»:

Du skal stille diagnose,

Du skal ordne terapi,

Medens alt studentikose

drukner helt i slaveri.

Du skal kjenne hver bacille,

Hvert et trekk som fins ved dem,

men dog er det dobbelt ille

Owrens flukt rundt faktor fem.

Hvor ble det av faktor fem (V) i figur 1 som viser interne, eksterne og terminale koagulasjonskaskade?

\section{Haakon B. Benestad}

h.b.benestad@medisin.uio.no

Haakon B. Benestad (f. 1940) er professor emeritus ved Avdeling for fysiologi, Institutt for medisinske basalfag, Universitetet i Oslo. Ingen oppgitte interessekonflikter.

Litteratur

1. Tvedt THA, Holme PA, Bruserud O. En mann i 80-årene med muskelstivhet og hudblødninger. Tidsskr Nor Legeforen 2014; 134: 1058-61.

\section{Re: Elendig inneklima i sykehusene}

Når temaet er inneklima (1), er det rart at dere ikke setter fokus på hvordan ansatte forurenser inneluften selv, med parfymer og parfymerte hygieneprodukter. Dette er ofte en veldig stor kilde til forurensning av inneluften på andre arbeidsplasser (2).

Jeg har selv opplevd at det «stinker» parfyme av mange av de ansatte de gangene jeg har vært på sykehus. Selvfølgelig er det alvorlig med mugg og de andre årsakene til dårlig inneklima som beskrives i denne artikkelen, men det koster faktisk ingenting å bedre inneluften betraktelig, dersom de ansatte slutter med parfyme. I informasjonsskrivet til alle som kommer til planlagte innleggelser kan man oppfordre til å la parfymen bli igjen hjemme.

Ingun Klingsheim

ingunklings@hotmail.com

Ingun Klingsheim (f. 1965) er ingeniør i Tinde Bygg AS.

Ingen oppgitte interessekonflikter.

Litteratur

1. Feiring E. Elendig inneklima i sykehusene. Tidsskr Nor Legeforen 2014 : 134: 1073

2. Undersøk innemiljøet ditt med Kvalifisert skjønn- metoden (KSM). www. inneklima.com/index.asp?context=\&document=105 (16.6.14) 